\title{
PRESIDENTIAL DEBATES AND THE ELECTORAL FORTUNES OF POLITICAL PARTIES IN GHANA'S 2008 ELECTIONS
}

\section{RANSFORD EDWARD VAN GYAMPO}

\author{
Department of Political Science \\ University of Ghana, Legon, \\ Accra, Ghana
}

Email: vangyampo@yahoo.com

\section{ABSTRACT}

The year 2008 will probably go down in Ghanaian political history as unique for the manner in which the general elections were conducted. The elections, which were held in December, were preceded by a number of events inc/uding the famous presidential debates. This paper discusses the two presidential debates in Ghana, organized by the Institute of Economic Affairs (IEA-Ghana) in Accra and Tamale prior to the general elections. The debates provided an opportunity for the presidential aspirants of the four main political parties with representation in parliament to engage in the contest of ideas. Using findings of a survey of 100 respondents, representing a cross section of the Ghanaian population, the paper argues that presidential debates have a negligible role in positively affecting the electoral fortunes of political parties and contribute little in whipping up support for presidential aspirants, especially among undecided voters. Their role in consolidating Ghana's democracy, particularly in ensuring dialogue and participation of the people in decision making, however, remains largely positive in spite of the several flaws and challenges that characterize their conduct in Ghana. Consequently, it is recommended that measures be put in place to ensure successful conduct of presidential debates in Ghana in a manner that fully contribute to democratic consolidation and encourage voters, especially the 
undecided ones, to objectively make a good decision as to which presidential aspirant or political party to vote for during the actual elections.

KEY DESCRIPTORS: Presidential Debates, Democratic Consolidation, Electoral Fortunes, Political Parties and Undecided Voters

\section{INTRODUCTION}

The need to consolidate democracy has been the desire of many Ghanaians since the return of multi-party system in January 1993. Accordingly; efforts aimed at empowering the ordinary citizenry, including vulnerable groups and ensuring their effective participation in the electoral processes, including the conduct of presidential debates, have been applauded.

Since 2000, presidential debates have been organized by the Institute of Economic Affairs (IEA), Ghana for presidential aspirants of the various political parties in Ghana. The forum has been used by presidential aspirants to articulate their programmes and policy options and to answer questions from the public on their programmes and policies presented. The significance of presidential debates in determining the outcome of elections in advanced democracies like the United States of America is well known. President Jimmy Carter for instance won his position as the US president with presidential debate as a huge contributory factor (Jamieson \& Birdsell 1996). Indeed, President Ronald Reagan of the US could not have won the presidential race in 1980 without the key role played by presidential debates (ibid). In a CNN Report of November 4, 2008, it was asserted that one of the factors that led to massive support for Barack Obama, the then Presidential Candidate of the Democratic Party was the way and manner he was able to articulate his policy prescriptions in a calm, objective and straight-forward manner during the presidential debates. Implicitly, presidential debates have an additional role of 
helping voters, particularly the undecided ones to make an informed choice as to who to vote for in an election.

In response to several calls by the presidential aspirants of the four main political parties with representation in parliament for debates among themselves, the IEA-Ghana organized two presidential debates prior to the conduct of the December 2008 general elections. The first debate took place in Accra on $29^{\text {th }}$ October 2008 and the second in Tamale on $12^{\text {th }}$ November 2008. However, no serious academic research has been conducted into the specific significance of such debates, which have been held since 2000, in order to determine their effects on election outcomes. More importantly, no research has been conducted to find out the role of presidential debates in Ghana in influencing the decision of participants of such events and for that matter ensuring the consolidation of the democratic gains of the country.

Did the conduct of the 2008 presidential debates have any impact on the views and decisions of the participants? In what specific ways do presidential debates contribute to democratic consolidation in Ghana? This paper will attempt to address these issues. In addressing the issues, the paper is divided into different sections. The concept of presidential debate is defined, followed by a review of literature as well as a brief discussion on the concept of democratic consolidation. The methodology of the paper is stated, followed by discussions on the evolution of presidential debates and how they are organized in Ghana. The last section of the paper is devoted to analyses and discussions of the key findings of the study, recommendations and conclusion.

\section{CONCEPTUAL FRAMEWORK}

\section{Presidential Debates Defined}

Presidential debates are defined as events that seek to bring presidential aspirants before a restricted audience of citizens for 
purposeful dialogue and interaction in a manner that allows the citizens to either directly or indirectly solicit answers to pertinent questions posed to aspirants (Jamieson and Birdsell, 1990). In the USA, for instance, it has become customary for the main candidates (almost always the candidates of the two largest parties, currently the Democratic Party and the Republican Party) to engage in a debate. The topics discussed in the debate are often the most controversial issues of the time, and arguably elections have been nearly decided by these debates (Mungenast, 2008). Such debates are held late in the election cycle, after the political parties have nominated their candidates.

- Different formats have been used over the years in presidential debates in advanced democracies. These styles include the Town Hall Meetings, during which the electorate are given the opportunity to ask questions. There is also the Panel Approach, during which the debating participants are made to answer questions from a number of people. The other is the Single Moderator System, during which one person is made to ask the aspirants questions (Jonah, 2004).

\section{State/Current Thinking on Presidential Debates}

According to Kraus (1999), the American political system evolved with debates. Colonial assemblies debated the revolution, the constitutional convention debated the constitution and congress debated the law. These contests produced memorable speeches and launched political careers. However, presidential debates have been more than a political tool in early America (i.e., the USA). They served as a means of educating the youth, honing professional skills, demonstrating personal worth and enlightening the citizenry (ibid). These different purposes of presidential debates, overlapping in some respects and conflicting in others, combine to form the debate tradition of the early national period in the US and some of the expectations that remain today (ibid). 
Swerdlow (1987), however, argues that presidential debates are a modern television age creation. He noted that nominees of the two major parties in the United States did not debate until 1960, when Republican Vice President Richard Nixon faced John Kennedy, the junior Democratic Senator from Massachusetts. Although the 1960 debates were popular with the public and were broadcast nationally on network television, presidential debates took a hiatus until 1976. Their absence was due, for the most part, to incumbents refusing to debate and federal communications laws, which required equal time for all presidential candidates, even minor ones (Swerdlow, 1987). Swerdlow also notes that since 1976, debates have played an important role in presidential campaigns. Debates can rarely change the momentum of a campaign, but they can help candidates exploit an opponent's weakness, help deflect attacks, and provide a national audience with some new ideas (ibid).

In agreeing with Swerdlow, Jamieson and Birdsell (1990:89) noted that in 1976, Jimmy Carter benefited when President Ford stated, "There is no Soviet domination of Eastern Europe." The press played up Ford's remark as a major blunder, and many analysts thought it helped Jimmy Carter win the election. On events in 1980, they note that the debates allowed Ronald Reagan to present himself as a moderate and humorous candidate, shedding criticism by Jimmy Carter that he was conservative to the extreme. Reagan also used the first debate to outline his agenda to a national audience. Jamieson and Birdsell (1990) argued that Reagan could not have won the election without the debates. In 1984, Reagan again used humor to allay fears that he was too old to be president: "I will not make age an issue in this campaign. I am not going to exploit, for political purposes, my opponent's youth and inexperience." That remark drew a hearty laugh from the audience and from Democratic opponent Walter Mondale (ibid). In 1988, Democrat Michael Dukakis cemented his "wooden" image by responding to the question of what he would do if his wife was raped and murdered with a turgid reiteration of his oppo- 
sition to the death penalty (ibid). In 1992, Bill Clinton worked the new format of a "town hall" to its potential, empathizing with the audience's concern over the economy and health care (ibid:5). For Jamieson and Birdsell (1990), presidential debates are very useful particularly for swing voters who, before the debates, may not have seen the candidates without some type of media filter. Nevertheless, they added that sometimes, such events reaffirm people's opinions rather than change them (ibid).

Also, writing on the 2008 Presidential Debates in the USA, Taylor (2008) noted that the first presidential debate between then Senators Barack Obama of the Democratic Party and John McCain of the Republican Party in the US was watched by over 50 million viewers. The two primary issues at the fore of the debate were foreign policy and national security. The moderator for the debate, however, preemptively introduced an additional issue on the global financial crisis. Taylor (2008) argued that in presidential debates, candidates visibly strive to achieve presidential demeanors and noted that in the 2008 USA presidential debates, McCain adopted a strategy of avoiding direct eye-contact with his opponent while discussing Russia, Georgia, and Iraq, while Obama conversely decided to address the camera while speaking about his commitment to using direct diplomacy to deal with those countries. The presidential debates afforded the candidates the opportunity to articulate their policies on national as well as global issues in a manner that demonstrated a stark difference between them as far as policies were concerned (Taylor, 2008). Presidential debates provide the opportunity for the masses or electorate to analyze the diverse plans and programmes of the candidates so they can make rational and informed political choices in times of voting. This enhances voter freedom to choose between and among various policies (ibid).

On his part, Mungenast (2008) argued that the $15^{\text {th }}$ October 2008 presidential debate between Barack Obama and John McCain was the best pure debate of the 2008 USA presidential election. He 
explained that it allowed both candidates to get into the necessary specifics of their respective campaigns. In his view, the success of the debate must be credited to the moderator who pulled off "the most difficult task of the exceedingly difficult task of having both candidates actually debate each other" (ibid). The main difference between Bob Schieffer, moderator of the debate and the other previous moderators, was Schieffer's willingness to allow both candidates ample time to answer questions, but still challenging both candidates with thorough follow-up questions. He argued that McCain exhibited raw emotions, abandoning his faux folksiness while Obama was calm and cool, with a perplexed smile on his face for a good portion of the debate and responding directly to some of McCain's attacks and ignoring others but always maintaining an almost supernatural serenity. He argued that such attitude exhibited by McCain denied him the huge victory he needed to push him into the White House (ibid).

Schroeder (2008) also noted that presidential debates afford the opportunity for the electorate to make informed choices on whom to vote for or not in an election. He noted that during presidential debates, every word of the policies of candidates, their gestures and facial expressions are magnified (ibid). He however, added that as long as presidential debates are controlled by their stars, the leading players will always have the license to behave as "prima donnas" (ibid: 17).

Writing on the 2008 Canadian presidential debate, Mansbridge (2008) noted that Canadian political leaders argued over the economy as they tussled in the first of two televised debates ahead of the 14 October 2008 general election. In the debate, according to him, incumbent Prime Minister Stephen Harper insisted that Canada's economy was solid as his rivals attacked him of being an "economic risk" and not believing in the role of government. Harper was accused of being a fan of the laissez-faire approach to the economy just like his counterpart, George W. Bush in the USA. According to Mansbridge (2008), rivals of Prime Minister Harper, 
Liberal leader Stephen Dion and separatist Bloc Quebecois leader Gilles Duceppe, Green Party leader Elizabeth May and Jack Layton of the New Democrats accused hime of failed economic policies. They argued that the laissez-faire approach to the economy had disastrous consequences by citing the unfolding economic crisis in the United States as a result of this approach. Mansbridge (2008) noted that though Prime Minister Harper conceded that the country faced "a period of uncertainty" he however, insisted that the fundamentals were "strong" and that Canada had a budget surplus.

Jonah (2004) defined presidential debate as a forum where presidential aspirants or those who seek to govern are brought together on a common platform to dialogue and discuss their policies and programmes with the electorate. For him just like others have argued earlier, presidential debates are effective ways of involving the electorate in political processes. They provide a platform for voters to be adequately informed and for critically assessing the suitability of various presidential aspirants at a given time (ibid). Jonah notes that a major attribute of good and democratic governance is political tolerance. This ensures that those in government take the views of the masses and other Civil Society Organizations, which may be expressed in the form of criticisms or praises in good fate without victimizing them. According to him, the conduct of presidential debates, to a large extent, also ensures dialogue and some amount of tolerance among the candidates (ibid). A calming of political tension will certainly ensue from this activity argues Jonah (2004). Obviously, seeing the various candidates on a common platform and engaging in a contest of ideas has a very positive trickling-down effect on supporters.

The works reviewed give broad insights and perspectives about presidential debates in general and particularly among developed and highly literate democratic societies like the USA and Canada. This paper, however, focuses on Ghana and addresses the question as to whether presidential debates can influence voters in 
making a decision on whom to vote for in the run up to Ghana's December 2008 general elections. It looks at the specific ways in which presidential debates in Ghana can help consolidate the democratic gains of the country. Finally, it discusses some of the major setbacks of presidential debates in Ghana and how they can be dealt with to help consolidate democracy in Ghana.

Deferring to Jonah (2004), events such as presidential debates in Ghana are helpful in consolidating the democratic gains made. Implicitly, the significance and contributions of the conduct of presidential debates in young democracies like Ghana must not be limited to the extent to which they affect the electoral fortunes of political parties. Instead, their ultimate impact in consolidating democracy must also be interrogated in all discourse and appreciated. What then is democratic consolidation? The next section briefly discusses the concept and establishes its relationship with the conduct of presidential debates.

\section{Democratic Consolidation}

Democratic consolidation is the process by which a new democracy matures, in a way that makes it unlikely to revert to authoritarianism without an external shock (O'Donnell, 1996). Scheduler (1998) also sees, democratic consolidation as embracing the following: popular legitimation; the diffusion of democratic values; the neutralization of anti-system actors; civilian supremacy over the military; elimination of authoritarian enclaves; party building; the organization of functional interests; the stabilization of electoral rules; the routinization of politics; the decentralization of state power to assure popular participation of the bulk of society in the political process; the introduction of mechanisms of direct democracy; and judicial reform; etc. For Gasiorowski and Power (1998), democratic consolidation connotes an acceptable qualitative improvement in democratic practices. 
At the very minimum, democracy requires the existence of free, fair, and recurring elections that allow the citizenry of a country to choose representative leaders. While elections are a fundamental prerequisite of democratic consolidation, the presence of a functioning electoral system does not automatically ensure the existence of true demoçracy or rule out the possibility of authoritarion structures and practices (Adcock, 2005). To clarify the minimal requirements of democratic consolidation, $O$ 'Donnell (1996) uses Dahl's (1971) concept of "polyarchy," which outlines a useful set of guidelines for democratic consolidation. Polyarchy has six requirements in addition to free and fair elections: universal suffrage, the right to run for office, freedom of expression, alternative-sources of information, and freedom of association ( $O^{\prime}$ Donnell, 1996). These prerequisites should ensure that democracy functions at a minimal level: that is, competition occurs for public office, political participation is useful and inclusive, and civil rights and liberties are protected (ibid). While Dahl's (1971) minimal prerequisites for democracy are generally agreed upon, it is the unique political and social phenomena inherent to every fledgling democracy such as poverty, antidemocratic norms, weak institutions and military guardianship that muddy concepts like democratic consolidation and make generalization nearly impossible (Adcock, 2005). Further complicating the situation, even when phenomena are roughly the same, competing terms sometimes exist to describe them. For example, "guided democracy," "protected democracy," "tutelary democracy," "democradura" (i.e., hard democracy) and "dictablanda" (i.e., soft dictatorship) all describe a situation in which the military continues to exercise power in areas normally reserved for civilian branches of government (Adcock, 2005). It was this lack of precision that led political scientists Collier and Levitsky to describe the study of democratic consolidation as "Democracy with Adjectives" (Collier and Levitsky, 1997:430).

On the basis of the liberal conceptualization of democratic consolidation, the question is whether there have been any appreciable improvements in terms of democratic consolidation since the re- 
turn of Ghana to constitutional government in January 1993. If participation of the bulk of the population, including vulnerable groups, in decisions constitute a fundamental pre-requisite for democratic consolidation, then one of the recent events that has emerged on the Ghanaian democratic scene which could further enhance political participation and also promote dialogue, is the conduct of presidential debates. Presidential debates broadly ensure that the masses or citizenry are furnished with ample information so that they can exercise their freedom of choice rationally and make well informed decisions regarding who to vote for before elections are held (Taylor, 2008). Again, the principle of social and political accountability is enhanced through the conduct of - such debates as presidential hiopefuls are brought face-to-face with the voting public to justify why they should be given the mandate as leaders (Jonah, 2004). Indeed, audiences of the presidential debates in Ghana are drawn from a cross-section of Ghanaians representing various civil society organizations in the country in a manner that ensures that the ordinary Ghanaian is represented (ibid).

\section{METHODOLOGY}

The total list of the $\mathbf{3 0 0}$ member audience of the debate in Accra and Tamale drawn by the IEA-Ghana was used as the population. Fifty (50) respondents were selected from the audience list of the Accra debate. The same number of respondents $(50)$ was also selected from audience list of the Tamale debate. The audiences of the two debates comprised representatives of political parties, civil society organizations, clergy, traditional rulers, diplomats, media practitioners and public servants. In all, 100 respondents were selected using the systematic random sampling technique. Every sixth person who either wrote to the IEA-Ghana or made a telephone call to confirm his or her participation was interviewed before and after the debate on telephone. The respondents who comprised 41 women and 59 men were twenty-eight (28) representatives of political parties; two (2) diplomats; forty-two (48) 
representatives of civil society organizations including the church and media; fifteen (15) public servants; and seven (7) traditional authorities.

All the respondents were literate with at least secondary school level of education and were aged between 30 and 65 years. A major setback of the study was that it did not factor views of the masses who viewed the debates on television from their homes and elsewhere into consideration. This would have been ideal; however, time constraints worked against the desire to have the direct views of the masses reflected in the outcome of the survey. The findings may therefore, not give an entirely accurate view. .However, they. may to a: large extent reflect the views, and concerns of the masses.

The specific questions that were asked before the debate were as follows:

1. Have you attended or watched any of the presidential debates organized in Ghana by the IEA since 2000?;

2. In your view, do you think such events can help consolidate the democratic gains made in Ghana?;

3. In what specific ways can presidential debates help consolidate democracy in Ghana; and

4. Do you have preference for any of the presidential aspirants?

In the post debate interview, the following questions were asked:

1. Did the debate influence you in changing your views about a particular candidate?;

2. If your answer is 'No' could you please give reason (s)?;

3. Will you vote in the December 2008 general elections?;

4. If your answer to the above question is "No" or "Not Sure", will you have had a different response if you had been convinced by the candidates during the presidential debates?"; and

5. What do you think were some of the challenges of the debate? 
The responses would be analyzed in a later section of the paper. Next is a brief review of how the concept of presidential debates evolved and how they are organized in Ghana in the next two sections.

\section{THE EVOLUTION OF PRESIDENTIAL DEBATES}

\section{Globally}

Abraham Lincoin and Stephen Douglas of the USA squared off in the first ever presidential debate in 1858, clashing on slavery and the union. It was however, the four sessions of debate between Democratic candidate John . F. Kennedy and the Republican nomi-. nee, Richard Nixon that marked the watershed in the history of presidential debates worldwide; largely due to the then newlydiscovered power of television and marketing (Kraus, 1999).

To ensure that debates as a permanent part of every general election, provide the best information to viewers and listeners, the Commission on Presidential Debates (CPD) was established in the USA in 1987. Primarily, the CPD is to sponsor and produce debates for the United States presidential and vice presidential candidates and to undertake research and educational activities relating to the debates. The CPD, therefore, sponsored all the presidential debates in 1988, 1992, 1996, 2000, 2004 and 2008. To meet its ongoing goal of educating voters, the CPD is engaged in various activities beyond producing and sponsoring the presidential debates. Its staff prepares educational materials and conducts research to improve the quality of debates. Further, the CPD provides technical assistance to emerging democracies and others interested in establishing debate traditions in their countries. In recent years, the CPD worked with groups from Brazil, Ecuador, Jamaica, Japan, Mexico, Namibia, Nicaragua, Nigeria, Russia, South Africa, Taiwan and the Ukraine, among others,

Presidential debates have continued their evolution and have gained popularity in countries such as the United Kingdom (UK), 
Canada, Cambodia, Tanzania, and recently, Ghana. Even though their format, thematic content and concept may differ from place to place, presidential debates are gradually becoming one of the highlights of many political calendars in advanced democracies (Jonah, 2004). In Ghana, the path that the nation treaded in her journey towards democratic advancement meant that the culture of presidential debates was never ingrained into the national political psyche. However as the country's circuitous democratic path became linear from 1996, presidential debates became a standard fare in the country's political dispensation (Jonah, 2004).

\section{Ghana}

The first ever-presidential debate in Ghana was organized in the year 2000 under the sponsorship of the IEA-Ghana. The debate was attended by the then presidential aspirants; namely, Charles Wereko Brobbey of the United Ghana Movement (UGM), Dan Lartey of the Great Consolidated People's Party (GCPP), Edward Mahama of the People's National Convention (PNC), George Hagan of the Convention People's Party (CPP), Goosie Tanoh of the National Reform Party (NRP) and John Agyekum Kufuor of the New Patriotic Party (NPP). The candidate of the National Democratic Congress (NDC), the then ruling party, John Evans Atta Mills was, however, absent (Jonah, 2004).

Prior to the 2004 general elections, IEA-Ghana organized another debate on $16^{\text {th }}$. November 2004 for the four main presidential aspirants. However, the candidate for the then ruling party, J.A. Kufuor of the NPP failed to attend due to a last minute cancellation although he had earlier committed to participate in the event. The debate was therefore between George Aggudey of the Convention People's Party (CPP), Edward Mahama of the People's National Convention (PNC), and J.EA. Mills of the National Democratic Congress (Jonah, 2004). Thus, for 2000 and 2004, the candidates of the incumbent parties failed to participate in the debates. This was to change during the 2008 General Election debates. 
IEA-Ghana again organized two presidential debates in 2008, prior to the general elections. The first debate took place in Accra on the October 29, 2008 and the second, in Tamale on November 12, 2008. The debates were attended by all the presidential candidates of the four main political parties with representation in parliament. They were Nana A.D. Akuffo Addo of the NPP, J.E.A. Mills of the NDC, Paa Kwesi Nduom of the CPP and Edward Mahama of the PNC.

Although presidential debates have become a part of the electoral process, it remains in the domains of civil society. Since 1992, Ghanaian civil society has taken keen interest and played the lead role of ensuring that the much anticipated débates occur. Another interesting development about debates in Ghana, especially during the 2008 general elections, is the use of public interest forum, where presidential aspirants or their representatives share their manifestos and solicit support. In 2008, aspirants initiated or were invited by special interest groups such as the Association of Ghana Industries, Kwame Nkrumah University of Science and Technologies and the Women's Movement for encounters meant to share views on the particular interests of the constituency.

\section{ORGANIZING PRESIDENTIAL DEBATES: THE PROCESS}

The IEA-Ghana has been the only organization that has organized successive presidential debates in Ghana since 2000. In organizing debates, there are certain basic processes that are observed. First, the IEA-Ghana writes to the various presidential aspirants to get their commitment to participate in the debate. On receiving a letter confirming their willingness to participate in the debate, the IEAGhana issues a press statement about its intention to organize the debates and names of the presidential aspirants who are likely to participate. This is the second stage. The third stage involves writing to the various civil society organizations and asking them to submit questions related to their areas or activity as well as other socio-economic, political and governance issues of the country. 
The IEA also places several announcements in the dailies, calling on individuals who may want certain issues to be addressed in the debate to also submit their questions. The fourth stage involves the setting up of a presidential debate committee. This is done in collaboration with representatives of the presidential aspirants who have indicated their intention to participate in the debate. The committee is normally made up of eminent statesmen, representatives of civil society groups including the church, media and traditional authorities, as well as other eminent public servants. What the committee does is to review and harmonize the questions submitted; set the rules of procedure to govern the debates; fix the date and time for the debate; and appoint a moderator and an announcer for the debate: The decisions taken ore-communicated to: the presidential aspirants through their representatives. The fifth stage is the rehearsal stage. The IEA-Ghana rehearses the sitting arrangements, stage manners as well as how questions ought to be answered with the representatives of the presidential aspirants. The representatives of the aspirants are then expected to communicate all rehearsals and rules that would govern the debate to the aspirants. The debate committee also formally communicates the rules to the presidential candidates. On the debate day, the announcer reads the rules to the candidates and the audience present, introduces the moderator(s) and then hands over the debate to the moderator(s) who proceed(s) with the questions.

\section{RESPONDENT PERSPECTIVES BEFORE THE 2008 PRESIDENTIAL DEBATES}

This stage consists of analysis of the views of respondents selected prior to the conduct of the debates. The first question asked was "Have you attended or watched any of the presidential debates organized in Ghana by the IEA-Ghana since 2000 ?"Responding to the question, 87 out of the 100 respondents said they had either watched or attended the presidential debates organized by the IEA-Ghana since 2000 . Thirteen (13) respondents however, claimed otherwise. This somewhat implies that most of 
the participants are keen observers of what goes on in the Ghanaian political scene.

The second question posed was "In your view, do you think such events can help consolidate the democratic gains made in Ghana?" In response, all the respondents noted that the conduct of presidential debates is a giant leap towards Ghana's democratic practice and commended the IEA-Ghana for initiating such a noble idea in Ghana. Many people in Ghana remain positive and optimistic about the significant role the conduct of presidential debates could play in consolidating the country's democracy.

As a follow-up to the second question; respondents asked to state the specific ways in which presidential debates can help consolidate democracy in Ghana. In response $\mathbf{3 0}$ out of the respondents noted that presidential debates ensure the participation of the electorate, including the marginalized and disadvantaged, in the democratic and electoral processes. Indeed, those who participate as audience in the presidential debates are drawn from civil society organizations in Ghana who to a large extent, represent a cross-section of the ordinary Ghanaian. Again, the questions asked at such debates emanate directly from the public and also, indirectly from the various civil society organizations in Ghana. Eleven (11) respondents also said the conduct of presidential debates could also ensure and deepen dialogue between the electorate and the presidential hopefuls while 16 respondents argued that such events calm down political tensions in the country. The two main political parties, the NDC and NPP have all been in power and in opposition before. Incidentally, the CPP was also seen as the third force capable of causing an upset in the 2008 elections. This made the 2008 elections unique in terms of its competitiveness and the possibility of such intense competition raising the political tension. Twenty nine (29) respondents noted that presidential debates make leaders and would-be leaders accountable to the masses while 14 respondents claimed the forum gave meaning to their democratic right to exercise choice over policies, 
Ghana Joumal of Development Studies 6 (1) May 2009

parties and personalities, among others. See Table 1 below.

Table 1: How presidential debates consolidate democrccy in Ghana

\begin{tabular}{|l|l|}
\hline RESPONSE & FREQUENCY \\
\hline Participation of the electorate & 30 \\
\hline Dialogue & 11 \\
\hline Calming political tension & 16 \\
\hline Accountability & 29 \\
\hline Freedom of Choice & 14 \\
\hline TOTAL & 100 \\
\hline
\end{tabular}

Source: Field Survey, $20^{\text {th }}-28^{\text {th }}$ October 2008

Finally, respondents, prior to their participation in the debates were asked whether they supported any of the candidates participating in the presidential debates. Majority of the respondents to this question were undecided. Indeed, only 36 out of the total respondents said they had their own preferences among the aspirants while 2 respondents who happened to be the participating diplomats said they did not support any of the parties. Sixty-two (62) respondents said they were not decided as to who they would vote for. They therefore expressed the hope to be able to make up their minds after the debates. This response was quite fascinating because as indicated earlier, in the USA, for instance, the role of presidential debates in influencing undecided voters to vote in a particular way is enormous. However, in Ghana, one was not sure whether presidential debates had that role of influencing those who are undecided. It was therefore interesting to see how the two presidential debates in Ghana would fare in influencing the electorate and in particular, those who claimed to be undecided. 


\section{RESPONDENT PERSPECTIVES AFTER THE 2008 PRESIDENTIAL DEBATES}

The next set of questions was asked after the debates. The first question asked was "Did the debate influence you in changing your views about a particular candidate?" In response, 88 out of the 100 respondents said they were not convinced to change their views. They explained that the debate did not make any impact on them in deciding who to vote for or who not to vote for. Only 12 said the debate had an impact on them in deciding who to vote for. Indeed, according to Joy FM's (a local Radio Station in AccraGhana) team of reporters who covered the Tamale debate on Wednesday $12^{\text {th }}$ November 2008 , though the expectations of the local people was high, many of them were of the view that the outcome of the debate would not affect their choice.

All the 12 respondents were among the 62 undecided voters and they applauded the depth of knowledge and competence displayed by Paa Kwesi Nduom, the CPP flag bearer. They therefore tipped him to be the one they would support in the December 2008 elections. The study revealed also that among the 88 respondents who said the debate did not make any impact on them in deciding who to vote for, an overwhelming majority $(50)$ were undecided voters while 36 were already die hard supporters of one particular party or the other. Only 2 claimed they were not in support of any political party in Ghana. This suggests that the debates had little impact on the undecided voters, as majority of them were still undecided even after the two debates.

The second question in the post-debate interview was for respondents to explain why they said the debate had no impact on them in deciding who to vote for. Specifically, the 88 respondents who said the debate had no impact were asked the question as follows: "If your answer to the first question is 'No' could you please give reason (s)?" Responding to this question, 19 respondents noted that the candidates exhibited poor communication skills to ade- 
quately articulate their policy positions within the limited time given them and misconstrue the forum to be party rallies. Twentyeight (28) pointed out that there were basically no stark differences between the policy positions of the candidates since they seemed to have the same approaches to solving national problems. Thirty (30) respondents aiso noted that the candidates lacked convincing arguments to win their votes because their responses to the questions were shallow. Finally, 11 respondents argued that the candidates lacked adequate knowledge over the issues. Table 2 captures the responses.

Table 2: Reasons why the debates had no impact

\begin{tabular}{|l|l|}
\hline REASONS & $\begin{array}{l}\text { FRE- } \\
\text { QUENCY }\end{array}$ \\
\hline $\begin{array}{l}\text { Lack of communication skills to articulate policy posi- } \\
\text { tion }\end{array}$ & 19 \\
\hline No stark differences in policy positions & 28 \\
\hline Lack of convincing arguments to win votes & 30 \\
\hline $\begin{array}{l}\text { Lack of adequate knowledge over the issues to be ad- } \\
\text { dressed }\end{array}$ & 11 \\
\hline TOTAL & 88 \\
\hline
\end{tabular}

Source: Field Survey, $20^{\text {th }}$ October- $16^{\text {th }}$ November 2008

The third question sought to find whether the respondents were going to vote in the December 2008 general elections at all. This question was specifically directed to the 88 respondents who claimed they were not convinced by the candidates during the presidential debates. In response, 49 respondents could not tell whether they would be voting or not while 26 said they would be voting though they remain undecided. Thirteen (13) respondents stated categorically that they were not going to vote because they were not convinced by any of the aspirants during the presidential debates. Impliedly, a large chunk of the respondents may possibly not exercise their franchise and those who would, may do so based on factors other than performance on the debates. 
The fourth question sought to find out whether the respondents would have had a different answer if the presidential aspirants had succeeded in convincing them during the presidential debates. This question was directed to the 62 respondents who either said they were not going to vote or could not tell whether they would be voting. Responding to the question, all the 62 respondents answered in the affirmative, suggesting that they were really looking up to the outcome of the presidential debates so they could make an informed decision as to who to vote for. However, most of them were left in limbo after the debates.

The fifth question in the post-debate interview asked respondents to mention some of the factors that may have worked against the conduct of the presidential debates. In response, 8 respondents said, participants of the debates were the elites and eminent people in society and had little room for the ordinary person on the street and in the hinterland. Similarly, 10 respondents cited the fact that the debate could not be patronized by many ordinary people in the rural communities where the bulk of the Ghanaian population resides because most of them do not have television sets to watch the debates and to learn about the policies of the candidates. Even those who had televisions could not be guaranteed to watch the debates due of power fluctuations and/or outages. The first two responses somewhat shows a gap between people perceived to be representing the masses and the masses themselves. The question is: "Do the audience or participants of the debates, selected by the organizers, actually represent the masses? This could be an important subject for thorough discussion in another paper. Suffice it to say that this finding somewhat contradicts Taylor's (2008) view that presidential debates allow the masses to play a key role in selecting their leader.

On the challenges of the debate, 30 respondents noted that the time allowed for answering questions by candidates was too short and the sounding of the bell to signify that one had exceeded the time allowed in answering a particular question worked against 
the success of the debates as well as the ability of the candidates to clarify their key policy positions. Admittedly, the time allowed for answering questions was too short. However, the inability of the presidential aspirants to articulate their views and responses in a simple and straight forward manner was also exposed. This, arguably, does not signify a mastery over the key issues that confront the populace. Twenty-three (23) respondents also claimed the events could not be christened debates in the proper sense because they were merely a little beyond question and answer series for the candidates. Presidential debates must go beyond mere question and answer series. As noted earlier, the conduct of presidential debate must ensure purposeful dialogue and interaction between presidential aspirants and the audience of citizens as aptly argued by Jamieson and Birdsell (1990).

Finally, some respondents (29) argued that the moderators of the debates lacked adequate familiarity over the issues they presented to the candidates as questions. This worked against the ability of the moderators to ask effective, insightful, in-depth but also challenging and thought-provoking follow-up questions. As Mungenast (2008) observed, the success of the October 15, 2008 presidential debate in the USA was largely as a result of the moderator's familiarity with the key issues and his ability to ask thoughtprovoking and thorough follow-up questions. Below is Table 3 depicting challenges of the $\mathbf{2 0 0 8}$ presidential debates in Ghana.

Table 3: Challenges of the debates?

\begin{tabular}{|l|l|}
\hline CHALLENGE & FREQUENCY \\
\hline Elite audience and participants & 8 \\
\hline Not all rural people could watch the debates on TV & 10 \\
\hline Limited time for answering questions & 30 \\
\hline A little beyond mere question and answer series & 23 \\
\hline Deficient Moderators & 29 \\
\hline TOTAL & 100 \\
\hline
\end{tabular}

Source: Field Survey, $20^{\text {th }}$ October- $16^{\text {th }}$ November 2008 


\section{GENERAL OBSERVATIONS AND RECOMMENDATIONS}

The study shows that presidential debates, though a novel phenomenon in Ghana's democratic dispensation can help strengthen the pillars of Ghana's democracy. Indeed, when institutionalized on the political calendar of the country, it could contribute immensely towards democratic consolidation by way of ensuring tolerance, dialogue, and participation (indirect) of a cross section of the population. Again, the conduct of presidential debates in countries like Ghana where elections are sometimes characterized with violence and tension, debates could be useful in calming down political tensions and for fostering wa-feeling and unity among candidates, which could in turn trickle down to their followers or supporters. Moreover, presidential debates bring the candidates face to face with voters, particularly the undecided ones, and have the potential to guarantee them their freedom of choice in terms of policies and personalities with potential for ensuring that voter decisions are based on issues.

Issue-based politics is crucial in Ghana, considering the many calls by civil society organizations on politicians to desist from personality attacks and focus their campaigns on issues in the electioneering process. Indeed, it was for this very reason that several evening encounters were organized by the IEA-Ghana for the presidential candidates in the December 2008 elections prior to the presidential debates. The credentials of presidential debates in terms of contributing to Ghana's democratic consolidation can therefore not be relegated to the background.

However, the debates played little role in influencing undecided voters to make a decision as to who to vote for. Only a small portion of the undecided voters were influenced by the debates. For a large and preponderant majority of them, the debates could not help them in making a decision as to who to vote for. For these undecided voters, the candidates were deficient in communicating, in a more articulate manner, their policy positions within the limited time frame available to them. This, for the respondents, meant 
a lack of familiarity and easy grasp over the issues that affect Ghana as a nation. Many of the undecided voters noted the policies of the candidates were virtually no different from each other and that the candidates could not advance convincing arguments to win their support.

For presidential debates to win the attention of voters, particularly the support of the undecided ones, it is important for candidates to sharpen their political communication skills and to have an adequate familiarity over the key issues affecting the country so they can appropriately respond to them within any limited time frame, when called upon to do so at any forum. This would also help in convincing the electorate to vote for them. Again, candidates should endeavour to evolve programmes and policy options that will stand in stark contrast with others. Some of the Ghanaians, as the result of the study indicates, are not pleased with the seemingly same approach adopted by all the political parties in dealing with national issues. Talking about virtually the same approach in solving national problems by the candidates takes away the excitement and attractiveness of their policies. This certainly would not attract voters, particularly those who are undecided.

Moreover, presidential debates could be organized at the regional as well as constituency levels to bring the event and candidates closer to the people at the grass roots, who may not be able to afford the luxury of watching the events on television sets due to poverty or lack of power. Even though the town hall meetings that are organized by IEA-Ghana and the Ghana Center for Democratic Development (CDD-Ghana) for parliamentary aspirants in the various constituencies are good and commendable, they reach only a restricted audience. As such, they should not be used as substitute for the proposal to have presidential debates close to the people at the grass roots.

Future debates must also be debates in the real sense of the word. A look at the presidential debates organized for John McCain and 
Barack Obama in the USA, prior to the country's elections on November 4, 2008 revealed that the candidates had extensive familiarity and grasp over the key issues and were quick to puncture holes in the policy options of their opponents before firmly making their own positions on an issue. In these debates, the moderators demonstrated familiarity with the issues they posed to the candidates and asked thought-provoking and insightful follow-up questions to unearth the competence and preparedness of the candidates. The moderators were also not destructive in the way they signaled to the aspirants on their time limits. This does not mean candidates were free to disregard the need to abide by time in making their positions on issues. Where necessary, they were prompted by the belt but as much as possible, candidates were made aware through the comments and gestures of the moderators of the need to make their positions known within their given time frame. The IEA-Ghana may want to take a cue from the conduct of presidential debates in other countries like the USSA in order to enrich future debates in Ghana in a manner that would be beneficial to the electorate and in particular, undecided voters.

Finally, the following general guidelines can also be helpful in conducting successful debates. First is the budget for the debate. How much a debate will cost depends on the size of the production, promotion, security, rental of a debate hall and dozens of other things. Organizers of the event must think far ahead about the budget and how to finance the events. Second, the size of the audience must be considered in the selection of a debate hall and debate site must be as neutral as possible. As much as possible, organizers of such events should look for venues that they might be able to use without incurring major expenses. These sites may include civic centers, school auditoriums and public parks. Moreover, printed materials in terms of programme outlines, posters, media credentials and audience tickets are helpful in promoting the debate. They also serve as souvenirs and as a means to give credit to the organizations that have supported the events. Further, the organizers must guarantee the security of the participants 
and the audience. Areas where debate related equipment and materials are stored must be put under lock and key.

Additionally, organizers must think about the internet when planning a debate. A website can be used to promote the date and location of the debate, solicit volunteers and donors, handle ticket requests, acknowledge sponsors and receive a post-debate feedback. Again, depending on the size of the debate, one can consider selecting a debate hall that offers space nearby for a separate media center. This center provides a location for journalists to work before and after the debate. For those journalists who are unable to be in the debate hall, the media center can serve as a viewing area. It also provides room for post debate interviews and; commentary. In the past, debates sponsored by the Commission for Presidential Debates in the USA had attracted well over 2000 journalists, making a media center essential (Lemert et al, 1991).

Accessibility should be an important consideration. It is also important to ensure that a chosen site does not cripple the transport system of the town or city. The site should be carefully to allow for free flow of vehicles to and from the event venue but also in the result of the community. Organizers should consider providing bussing participants from alternate parking lots to the event venue to ease flow. The debate site should be accessible to the participants, the public and the media. Organizers of presidential debates must consider soliciting feedback about the strengths and weaknesses of the Debate, so they can make amends where they fall short. Finally, participants should be educated on the real essence of presidential debates in developing countries like Ghana, which is not necessarily to sway votes but to promote dialogue between and among aspirants and the electorate and to make aspirants accountable to the electorate, among others. This is to ensure that all aspirants treat the debates not with contempt but with all the seriousness that they deserve. 


\section{CONCLUSION}

Even though the conduct of presidential debates in Ghana may not benefit politicians in terms of swaying voters and positively affecting their electoral fortunes, it nevertheless is an important tool which when institutionalized would help consolidate the democratic gains of the country. In the USA, for instance, the potential role of presidential debates in influencing voters, particularly the undecided, is perceived to be enormous. Even though the findings of this study are relative to the data and hence not absolute, it can plausibly be argued that Ghana would certainly get to the level in her democratic development and maturity where events like presidential debates would play a key role in influencing voters to vote for a particular candidate on the basis of issues: policies and programmes. Until the country gets to that era in its drive towards democratic maturity, all efforts must be made to sustain, institutionalize and improve on the conduct of presidential debates in Ghana so that they can contribute fully toward democratic consolidation and possibly influence the electorate to decide objectively on who to vote for and which policies to reject in the run up to general elections.

\section{REFERENCES}

Adcock, Chris (2005). "Violent Obstacles to Democratic Consolidation in three countries: Guatemala, Columbia and Algeria" available at http://www.csa.com/discoveryguides/demo/overview.php. Accessed on 10th August 2008.

Collier, David and Steven Levitsky (1997). "Democracy With Adjectives: Conceptual Innovation in Comparative Research," World Politics. Vol. 49, No. 3, (April), p. 430.

Dahl, Robert (1971). Polyarchy: Participation and Opposition, New Haven: Yale University Press, pp3-5. 
Gasiorowski, M.J and Power Timothy (1998). "The Structural Determinants of Democratic Consolidation". Comparative Political Studies, Vol. 31, No. 6, pp740-758.

Jamieson, Kathleen and Birdsell, David (1996). "Presidential Debates: The challenge of creating an informed electorate available at unw.cgi.com/ALLPOLITICS/1996/debates/history. Accessed on July 15th 2008.

Jonah, Kwesi (2004). "The 2004 Presidential Debate in Ghana", mimeo, Accra: Institute of Economic Affairs, pp 2-10.

Kraus, Sydney (1999). Televised Presidentiäl Debates and Püblic Policy. New Jersey: Lawrence Erlbaum and ASSOCIATES Inc. pp.17-18.

Mansbridge, Peter (2008). "Rivals Feud in Canada Poll Debate available at http://news.bbc.co.uk/1/hi/world/ americas 17647887.stm. Accessed on 10th August 2008.

Mungenast, Eric (2008). "A look at the October 15, 2008 Debate" available at www.us-elections.suite101.com/article.cfm/ alookattheoctober 152008debate. Accessed on 15th October 2008.

O'Donnell, Guillermo (1996). "Illusions about Consolidation," Journal of Democracy, Vol. 7, No 2, (April), pp 34-51.

Swerdlow, Joel (1988). Presidential Debates: 1988 and Beyond. (New York: Oxford University Press) pp. 3-10.

Schedler, Andreas (1998). 'What is Democratic Consolidation?'. Journal of Democracy, Vol. 9 No 2. 
Schroeder, Alan (2008). Presidential Debates: 50 years of High Risk TV. New York: Columbia Univ. Press.

Taylor, Cheron (2008). "The 2008 US Presidential Debate" available at www.us-elections.suite101.com/ article.cfm/2008uspresidentialdebatemccainobama. Accessed on 17th October 2008. 